\title{
Uwagi o roli działania w świadomości ciała na marginesie „Ukąszenie komara...”
}

\author{
Przemysław Nowakowski \\ Zakład Epistemologii i Kognitywistyki \\ Uniwersytet Mikołaja Kopernika w Toruniu \\ pnowakowski[]avant.edu.pl \\ Otrzymano i zaakceptowano: czerwiec 2014; opublikowano: lato 2014.
}

\begin{abstract}
Abstrakt
Artykuł stanowi wprowadzenie do przekładu artykułu Frederique de Vignemont pt. „Ukąszenie komara przeciwko enaktywistycznemu ujęciu doświadczeń cielesnych”. We wprowadzeniu tym koncentrujemy się na relacji między cielesnymi działaniami a świadomością ciała i jej treścią przestrzenną.
\end{abstract}

Słowa kluczowe: świadomość ciała; treść przestrzenna; prawa sensomotoryczne; enaktywizm; słaba konstytucja.

W naszym wprowadzeniu do pracy Frederique de Vignemont skoncentrujemy się na problemie związku między świadomością ciała a działaniem. Kwestię tę odnajdujemy w pracach Frederique de Vignemont (w tym tomie oraz 2014a), a także w książce J. Kevina O'Regana (2011, rozdział 13). Sądzimy, że prezentowaną poniżej pracę można uznać za pierwszy wyraźny głos w debacie dotyczącej wspomnianego związku. Debacie, która - jak sądzimy - będzie trwać.

Związek między świadomością własnego ciała a działaniem można rozpatrywać z perspektywy roli działania $\mathrm{w}$ świadomości ciała (de Vignemont $\mathrm{w}$ tym tomie, 2014a) oraz z perspektywy roli świadomości ciała w działaniu (Wong 2010, Smith 2009). Już klasyczne prace Nielsena (1963), a następnie Fournereta i Jeanneroda (1997) oraz wiele innych kolejnych pracy wykazywało, że pomimo pewnej fenomenalnej oczywistości świadomość ciała odgrywa ograniczoną rolę w kontroli działania. A jak jest w przypadku odwrotnej zależności? Jaką rolę gra działanie w świadomości ciała? Tu zajmiemy się tym właśnie pytaniem. Pytaniem, które możemy sformułować następująco: czym różni się świadomość ciała działającego od ciała niedziałającego? 


\section{Głos pierwszy: o komarze}

De Vignemont (w tym tomie) w interesujący sposób krytykuje enaktywizm ${ }^{13}$. Twierdzi, że skoro enaktywiści za wzorcowy przykład percepcji uznają percepcję dotykową, może to oznaczać, że percepcja in extenso jest jak percepcja dotykowa, stanowi rodzaj działania, eksplorowania. Dodatkowo twierdzą oni, że we wszelkiej percepcji mają udział szczególne prawa sensomotoryczne, które odpowiadają za (pełną) treść naszej percepcji (do czego jeszcze wrócimy). W pracy de Vignemont prawa te wiązane są ze szczególnym rodzajem oczekiwań, że ruch przedmiotów w odniesieniu do ciała oraz ruch części ciała $\mathrm{w}$ odniesieniu do tych przedmiotów będzie generował określone zmiany w percepcji dotykowej. Wykazanie, że percepcja dotykowa nie spełnia warunków enaktywizmu, może być poważnym zagrożeniem nie tylko dla enaktywistycznej koncepcji dotyku, ale dla enaktywizmu w ogóle.

Powtórzmy: jeżeli percepcja dotykowa jest wzorcowym przykładem percepcji dla enaktywistów i wszystkie inne rodzaje percepcji są podobne do dotyku, to wykazanie, że percepcja dotykowa nie spełnia warunków ujęcia enaktywistycznego, będzie wykazaniem, że enaktywizm stoi przed poważnym problemem, a fortiori stoi przed nim enaktywistyczna koncepcja świadomości ciała. Tu autorka koncentruje się na przestrzennej treści świadomości ciała.

De Vignemont (w tym tomie) argumentuje przeciwko ujęciu enaktywistycznemu na dwa sposoby. Po pierwsze wykazuje, że w przypadku doświadczenia bardzo krótkiego i pasywnego dotyku niemożliwe jest wskazanie działania szczególnych praw łączących to doświadczenie z działaniem, praw, które zdaniem enaktywistów są konieczne zarówno do przeżywania samego doświadczenia, jak i jego lokalizacji (więcej o tych prawach poniżej). W swoich badaniach de Vignemont przywołuje przykład komara i pyta: jakiego rodzaju prawa sensomotoryczne odpowiadają za doświadczenie przelotnego i delikatnego kontaktu tego owada z ludzką skórą. Następnie wykazuje istnienie podwójnej dysocjacji między sensomotoryczną wiedza, jak (podstawową dla koncepcji enaktywistycznych) a przestrzenną treścią świadomości ciała. Wykazuje, że możliwe są zaburzenia wiedzy sensomotorycznej przy jednoczesnym zachowaniu lokalizacji w dotyku i odwrotnie. Jak pokazuje autorka, występowanie takiej dysocjacji jest poważnym wyzwaniem dla enaktywizmu.

\footnotetext{
${ }^{13} \mathrm{~W}$ swoich pracach de Vignemont nie dokonuje rozróżnienia ujęć enaktywistycznych i sensomotorycznych. Choć nie jest to powszechnie akceptowane ujęcie, to jednak w tym wprowadzeniu podążamy za de Vignemont.
} 


\section{Głos drugi: o prawach sensomotorycznych}

O przestrzennej treści świadomości ciała pisze O'Regan w sposób następujący (pamiętajmy, że gdy pisze o prawach, to ma na myśli prawa sensomotoryczne): „W czuciu dotyku nie ma nic więcej ponad fakt zarejestrowania przez mózg aktualnie zastosowanego prawa. (...) To, co uważamy za odczuwanie czegoś w określonej lokalizacji na powierzchni naszych ciał, oznacza tylko i wyłącznie zastosowano określonego prawa (O'Regan 2011: 158). Autor ten wyróżnia szereg praw czy też reguł, którymi rządzi się świadomość ciała (szczególnie świadomość dotykowa), podkreślając, że to właśnie one odpowiadają za treść tej świadomości, a szczególnie za jej treść przestrzenną (patrz: O'Regan 2011: 157).

Występowanie określonych reguł czy prawidłowości w postrzeganiu własnego ciała jest niezaprzeczalne. Jednak czy faktycznie wskazanie tych reguł wystarczy, by wyjaśnić treść świadomości własnego ciała? Czym są te prawa lub reguły, że mózg może je rejestrować? Czy istnieje bezpośredni dostęp do nich? Czy system poznawczy przechowuje wiedzę o nich? To tylko kilka pytań, które nasuwają się w kontekście enaktywistycznej koncepcji świadomości ciała.

Sądzimy, że system poznawczy może - i zapewne to czyni - śledzić własne zmiany i rejestrować pojawiające się regularności. Jednak śledzenie zmian i regularności to nie rejestrowanie praw. Wydaje się, że aby rejestrować, a tym bardziej wykorzystywać prawa, system musi dysponować zdolnościami, które wykraczają poza podstawowe ustalenia koncepcji enaktywistycznych.

Jednak dla przytaczanej tu autorki najważniejsze jest wykazanie, że istnieją takie doświadczenia, które nie mogą być powiązane z żadną wiedza, jak, z jakimikolwiek prawami sensomotorycznymi.

\section{Głos trzeci: o niedostępności przestrzeni ciała}

W ostatniej pracy de Vignemongt (2014a) rozszerza krytykę enaktywizmu. Wskazuje nie tylko na to, że możemy obserwować podwójną dysocjację między działaniem a świadomością ciała czy specjalny rodzaj doświadczenia dotykowego - to znaczy chwilowego i delikatnego dotyku pasywnego, który stanowi poważne wyzwanie dla enaktywistycznych koncepcji świadomości ciała - ale i na fakt istnienia takich części ciała, których doświadczenie nie może się wiązać z żadnymi prawami sensomotorycznymi.

Powtórzmy: jeżeli świadomość ciała ma zależeć od pewnych praw sensomotorycznych, to dotykowa świadomość określonej części ciała powinna zależeć od tego, że:

(a) możemy poruszyć określoną częścią ciała,

(b) możemy dotknąć (poruszyć się w stronę) określonej części ciała. 
De Vignemont (2014a) wykazuje, że istnieją takie części ciała - na przykład niektóre partie pleców - którymi ani nie działamy, ani nie używany do eksploracji dotykowej dostępnych obiektów, a z pewnością już nie dotykamy nimi innych części ciała. Ponadto zwykle nie możemy sami owych części ciała dotknąć. Jeżeli faktycznie tak jest - a wydaje się, że tak - to nie może istnieć takie prawo sensomotoryczne, które by wyjaśniało (przestrzenną) treść doświadczenia tych części ciała. Tym samym enaktywistyczne ujęcie świadomości jest wadliwe.

\section{Głosem de Vignemont o krytyce de Vignemont}

W pracy dotyczącej multimodalnej świadomości ciała de Vignemont (2014b) analizuje rolę, jaką w tej świadomości odgrywa informacja wzrokowa, w tym - zagadnienie, czy jest to rola czysto przyczynowa, czy też konstytutywna. Wyniki tych rozważań autorki możemy wykorzystać w kontekście badań nad rolą działania w przestrzennej treści świadomości ciała.

Omawiając rolę widzenia (2014b), autorka miała do dyspozycji bardzo ograniczone i szczątkowe, ale jednak empiryczne badania nad doświadczeniem ciała $\mathrm{u}$ osób niewidomych. Czego możemy się dowiedzieć $\mathrm{z}$ analizy tych badań? Najważniejsze wnioski, jakie się nasuwają, to: (a) doświadczenie ciała u osób, które widzą, znacznie różni się od takiego doświadczenia u niewidomych; (b) osoby niewidome nie tracą świadomości ciała; (c) poważne zmiany w doświadczeniu ciała spowodowane są wrodzoną, a nie krótkotrwałą utratą informacji wzrokowej. Z tych wyników de Vignemont (2014b) wyprowadza wniosek, że rola, jaką pełni informacja wzrokowa, jest więcej niż tylko przyczynowa. Jednak fakt, że osoby niewidome nie tracą świadomości ciała, nie pozwala na uznanie tej roli za konstytutywną. Z tego powodu de Vignemont wyróżnia silną i słabą konstytucję. Można to opisać następująco:

Jeżeli a silnie konstytuuje z, to brak a oznacza brak z. Jeżeli b słabo konstytuuje y, to brak b oznacza znaczne zmiany w y. Oczywiście enaktywiści starają się wykazać, że prawa sensomotoryczne silnie konstytuują doświadczenie ciała. Dlatego argumenty de Vignemont ( $w$ tym numerze; 2014a) trafiają w enaktywizm. Jednak możliwa jest także słabsza interpretacja, zgodnie z którą prawa sensomotoryczne słabo konstytuują doświadczenie ciała. Takie ujęcie roli działania w świadomości ciała wydaje się bardziej adekwatne. Zgodne zarówno z enaktywizmem, jak i z intuicjami teoretycznymi stojącymi za pracami de Vignemont. 


\title{
Literatura
}

Fourneret, P., Jeannerod, M. 1998. Limited conscious monitoring of motor performance in normal subjects. Neuropsychologia, 36(11): 1133-1140.

Nielsen, T. I. 1963. Volition: A new experimental approach. Scandinavian journal of psychology, 4(1): 225-230.

O'Regan, J. K. 2011. Why red doesn't sound like a bell: Understanding the feel of consciousness. Oxford University Press.

Smith, A. J. T. 2009. Acting on (bodily) experience. Psyche, 15(1): 82-99.

De Vignemont, F. 2014a. Acting for bodily awareness. w: L. Shapiro, red. Routldege Handbook of embodied cognition: 287-295.

De Vignemont, F. 2014b. A multimodal conception of bodily awareness. Mind. (w dru$\mathrm{ku})$

De Vignemont, F. 2009. Bodily spatial content. Psyche, 15(1): 100-108.

Wong, H.Y. 2010. Bodily Awareness and Bodily Agency. w: T. O’Connor and C. Sandis red. A Companion to the Philosophy of Action. Blackwell: 227-135.

\begin{abstract}
In this introduction, the author discusses the article „A mosquito bite against the enactive approach to bodily experiences” by Frederique de Vignemont. The paper focuses on the relationship between bodily actions and bodily awareness in the context of its spatial content.
\end{abstract}

Keywords: bodily awareness; spatial content; sensorimotor laws; enactivism; weak constitution. 